\title{
RECONSTRUCTION OF CHILD CRIMINAL SANCTIONS IN PERSPECTIVE OF LAW NUMBER 11 YEAR 2012 CONCERNING JUSTICE CHILD CRIMINAL JUSTICE SYSTEM BASED ON JUSTICE VALUES
}

\author{
Akhmad Munawar $^{1}$, Gunarto $^{2}$, Anis Mashdurohatun $^{3 *}$, Sri Endah Wahyuningsih ${ }^{4}$ \\ 1 Doctoral Program in Law Sciences, Sultan Agung Islamic University, Semarang, Indonesia \\ Email: a.munawar@gmail.com \\ 2 Faculty of Law Sultan Agung Islamic University, Semarang, Indonesia \\ Email: gunarto@unissula.ac.id \\ 3 Faculty of Law Sultan Agung Islamic University, Semarang, Indonesia \\ Email: anism@unissula.ac.id \\ $4 \quad$ Faculty of Law Sultan Agung Islamic University, Semarang, Indonesia \\ Email: endah.w@unissula.ac.id \\ Corresponding Author
}

\section{Article Info:}

Article history:

Received date: 18.02 .2019

Revised date: 17.04.2019

Accepted date: 14.03.2020

Published date: 15.03 .2020

\section{To cite this document:}

Munawar, A., Gunarto.,

Mashdurohatun, A., \&

Wahyuningsih, S. E. (2020).

Reconstruction of Child Criminal

Sanctions in Perspective of Law

Number 11 Year 2012 Concerning

Justice Child Criminal Justice System

Based on Justice Value. International

Journal of Law, Government and

Communication, 5 (18),68-81.

DOI: 10.35631/IJLGC.518007.

\begin{abstract}
:
Children who are in conflict with the law are seen to need to be given physical and spiritual protection. Bearing in mind, the Court's decision is more likely to impose imprisonment sanctions. The United Nations in several Congresses has criticized imprisonment sanctions, besides having the potential to cause stigmatization in children, it is also ineffective and does not create a deterrent effect. This study aims to examine and to analyze the implementation of Child Criminal sanctions in the perspective of Law Number 11-year 2012 concerning the Child Criminal Justice System, to analyze the factors that influence child criminal sanctions that are not yet fair. The research question is how the reconstruction of child-based criminal sanctions based on justice is. This research is included in non-doctrinal research (empirical). It used three theories, namely the theory of criminal purpose to analyze the first problem, the dignified justice theory to analyze the second problem and progressive legal theory to analyze the third problem. The results found that the implementation of sanctions Crime against a child in conflict with a law imposed by a prison sentence, the Judge in his consideration emphasizes juridical considerations so that the criminal sanctions imposed on the child are not in accordance with teleological theory as the purpose of punishment. Criminal sanctions against children have not brought justice, among others, because several articles in Law Number 11-year 2012 concerning the Child Criminal Justice System still have weaknesses. Reconstruction of Articles that hinder the realization of fair criminal sanctions, namely Article 7 paragraph (2) Article 32 paragraph (2), Article 71 paragraph (1) letter e, Article 79 paragraph (1) and Article 81
\end{abstract}


paragraph (1) of the Law Number 11 the year 2012 concerning the Child Criminal Justice System.

Keywords:

Reconstruction; Criminal; Sanctions; Children; Justice

\section{Introduction}

The concept of the Pancasila Welfare State The state or government is obliged to regulate and direct the community as a whole or family. Especially at this time the Indonesian people have entered economic and legal globalization. ${ }^{1}$

In the Indonesian constitution, children have a strategic role that expressly states that "the state guarantees the right of every child to survival, growth and development and to protect them from violence and discrimination" (Article 28B of the 1945 Constitution of the Republic of Indonesia). Children are an inseparable part of human survival and the survival of a nation and state. Therefore, the best interests of children should be lived out as the best interests for the survival of humanity. Consequently, the provisions of Article 28B of the 1945 Constitution of the Republic of Indonesia need to be followed up by making government policies aimed at protecting children. ${ }^{2}$

Children need to be protected from the negative effects of rapid development, the flow of globalization in the field of communication and information, advances in science and technology, and changes in the style and way of life of some parents have brought fundamental social change to the Child. Behavior deviations or unlawful acts committed by the child, among others, are caused by factors outside the child.

The principle of legal protection for children must be in accordance with the Convention on the Rights of the Child as ratified by the government of the Republic of Indonesia with Presidential Decree No. 36 year 1990 concerning Ratification of Conventions on the Rights of the Child (Convention on Children's Rights).

Following up on Presidential Decree No. 36 year 1990 concerning Ratification of the Convention on the Rights of the Child, the government established Law Number 3 year 1997 concerning Juvenile Courts, intended to protect Children in Confront with the Law, so that children can meet their long-term future and provide opportunities for children so that through guidance they will get their identity to become independent, responsible and useful human beings for themselves, their families, communities, nations and countries. The law was later replaced with Law Number 11-year 2012 concerning the Child Criminal Justice System.

The substance regulated in Law Number 11-year 2012 concerning the Child Criminal Justice System, among others, regarding the placement of Children who undergo the judicial process can be placed in the Special Guidance Institution for Children (LPKA). The most basic

\footnotetext{
${ }^{1}$ Anis Mashdurohatun and M. Ali Mansyur Identifikasi Fair Use/Fair Dealing Hak Cipta Atas Buku Dalam Pengembangan Iptek Pada Pendidikan Tinggi Di Jawa Tengah, Yustisia. Vol. 4 No. 3 September - Desember 2015, see to Meta Suryani and Anis Mashdurohatun,Penegakan Hukum Terhadap Eksistensi Becak Bermotor Umum (Bentor) Berdasarkan Undang-Undang Nomor 22 Tahun 2009 Tentang Lalu Lintas Dan Angkutan Jalan, Jurnal Pembaharuan Hukum, Volume III No. 1 Januari - April 2016, page.22.

${ }^{2}$ Explanation of Law Number 11 of 2012 concerning Child Criminal Justice System.

Copyright $\odot$ GLOBAL ACADEMIC EXCELLENCE (M) SDN BHD - All rights reserved
} 
substance in the Act is the strict regulation of Restorative Justice and Diversion which is intended to avoid and keep children away from the judicial process so that they can avoid stigmatization, against Children against the Law and are expected to return to the environment socially reasonable. Therefore, the participation of all parties is needed in order to realize this issue. The process must aim at creating Restorative Justice, both for the Children and for the victims. Restorative justice is a process of diversion, that is, all parties involved in a particular crime jointly address the problem and create an obligation to make things better by involving victims, children, and the community in finding solutions to improve, reconcile and reassure heart that is not based on revenge.

Given the characteristics that are unique to the child and for the protection of children, cases of children facing the law must be tried in the Criminal Court of Children in the General Courts. The process of judicial proceedings of children from the time they were arrested, detained and tried for guidance must be carried out by special officials who understand the problem of the Child. However, before entering the judicial process, law enforcers, families, and communities must seek an out-of-court settlement process, namely through Diversion based on the Restorative Justice approach. ${ }^{3}$

The legal politics in Law No. 11 year 2012 concerning the Child Criminal Justice System can be seen in the consideration. The purpose of this law is to protect the dignity of children. They children are entitled to special protection, especially legal protection in the justice system. In addition, because Indonesia as a State Party to the Convention on the Rights of the Child which regulates the principle of legal protection for children has an obligation to provide special protection to children who are faced with the law. In Law Number 11-year 2012 concerning the Criminal Justice System of Children, cases of Children Conflicting with the Law do not have to be resolved through the court but are attempted to be resolved by restorative justice ${ }^{4}$ through diversion.

Although in Law Number 11-year 2012 concerning the Criminal Justice System the Child seeks to resolve Children Conflicting with the Law through diversion ${ }^{5}$. It aims to: a. achieves peace between victims and children; b. resolve child cases outside the court process; c. avoids the child from deprivation of liberty; $d$. encourages people to participate; and instill a sense of responsibility to the child ${ }^{6}$. However, not all children who conflict with the law can be resolved through diversion. Diversion can only be done against criminal acts which are threatened with imprisonment under 7 (seven) years; and not a repetition of a criminal act (Article 7 paragraph (2) letter a and letter $b$ ).

In Law No. 11 year 2012 concerning the Child Criminal Justice System, Article 2 regulates the principles that must be implemented in the Criminal Justice System. The Subtitles seize freedom and punishment as a last resort and avoid retaliation. ${ }^{7}$ In Article 2 letter i confirms the principle of deprivation of liberty and punishment as a last resort, deprivation of liberty in

\footnotetext{
${ }^{3}$ Ibid.

${ }^{4}$ Abintoro Prakoso, 2016, Pembaruan Sistem Peradilan Pidana Anak, Yogyakarta : Aswaja Pressindo, page 161 the main purpose of restorative justice is to repair or compensate the victims, to acknowledge the perpetrators of injuries suffered by the community as a result of their actions, conciliation and reconciliation of perpetrators, victims and the community. law by using awareness and conviction as a basis for improving community life.

${ }^{5}$ Article 1 number 7 of Act Number 11 of 2012 concerning Child Criminal Justice System, diversion is the transfer of settlement of Child cases from criminal justice processes to processes outside of criminal justice.

${ }^{6}$ Article 6 UURI No. 11 of 2012 concerning the Child Criminal Justice System.

${ }^{7}$ Article 2 of Law Number 11 of 2010 concerning the Child Criminal Justice System.

Copyright $\odot$ GLOBAL ACADEMIC EXCELLENCE (M) SDN BHD - All rights reserved
} 
this case is the imposition of imprisonment for children, imprisonment is a form of retributive action taken by the child, can only be done as a last resort (ultimum remedium).

According Sudarto, a criminal is a misery given by the state to someone who violates the provisions of the law (criminal law), intentionally to be felt as sorrow ${ }^{8}$. Giving sorrow or suffering that is intentionally imposed on someone who violates the provisions of the law (criminal law) is nothing but intended so that the person becomes deterrent. Criminal law intentionally imposes suffering in maintaining norms recognized in law. This sharp sanction in criminal law distinguishes it from other legal fields. This is the reason so that criminal law must be considered as the last means if sanctions or other legal measures are inadequate. ${ }^{9}$ on the other hand, it is deemed necessary to impose sanctions that ionize victims, especially children as victims of criminal acts. ${ }^{10}$

The problem of immoral crime against children arises because upholding criminal law has not been oriented to the value of justice, especially victim protection, but rather to the application of penalties on perpetrators. ${ }^{11}$

In Law Number 11-year 2012 concerning the Criminal Justice System of Children, Children who commit criminal acts can be sentenced to criminal or subject to action (maatregel), convicting children using a double track system. The provisions governing the type of criminal sanctions that can be imposed on Children are regulated in Article 71. On the other hand, the types of actions that can be imposed on Children are regulated in Article 82.

In the Child Criminal Justice System Law, the provisions governing criminal matters are regulated first than the provisions concerning actions against children. Thus, the imposition of imprisonment against children cannot be avoided. The imprisonment of imprisonment in children is also greatly affected by the community, especially victims who always want to impose criminal penalties against criminal offenders.

In Law Number 11 year 2012 concerning the Criminal Justice System of Children, Children who are in the judicial process and Children who are undergoing criminal periods are given special rights that are distinguished from adults, the rights of the Child in the judicial process and the rights of the Child being served a criminal period is also regulated in Article 3 point 7 not being arrested, detained or imprisoned, except as a last resort and in the shortest amount of time.

Although normatively the rights of Children in Conflict with the Law are strictly regulated but in its implementation it still cannot be implemented as a whole, this is influenced by several factors including the unavailability of facilities and infrastructure as well as the implementation of legislation (law enforcement) which is still not professional. No matter how well the rights given to children in the criminal justice process of children and those who are undergoing a criminal period, they will still feel depressed and confined.

\footnotetext{
${ }^{8}$ Sudarto, 1981, Kapita Selekta Hukum Pidana, Bandung; Alumni, page 109 - 110.

${ }^{9}$ Niniek Suparni, 1996, Eksistensi Pidana Denda Dalam Sistem Pidana dan Pemidanaan, Jakarta : Sinar Grafika, page 12 .

${ }^{10}$ Anis Mashdurohatun,2017, Wa Ode Khatija Rasia, Legal Protection On Children As Victims Of Human Trafficking Based On Justice Values, Jurnal Pembaharuan Hukum, Volume.4, Issue, 2, 2017.page.149.

${ }^{11}$ Sri Endah Wahyuningsih , Perlindungan Hukum Terhadap Anak Sebagai Korban Tindak Pidana Kesusilaan Dalam Hukum Pidana Positif Saat Ini, Jurnal Pembaharuan Hukum Volume III No. 2 Mei - Agustus 2016. Page. 172 
Article 71 paragraph (4) states that criminal sentences imposed on children are prohibited from violating the dignity of the child. The imposition of imprisonment (deprivation of liberty) on the child is not a violation of the dignity of the child. In Article 79 paragraph (1), "Criminal restrictions on freedom are enforced in the event that a child commits a serious crime or a criminal act accompanied by violence". In the Criminal Code (Criminal Code there is no clear classification of types of serious crimes, so there is no legal certainty. In Article 81 paragraph (1) Children are sentenced to imprisonment in LPKA if the circumstances and actions of the Child will endanger the community. Imprisonment in this article is also very subjective and unclear, because the condition or action of the child will only (not yet occur) and is still in the form of a prediction, from the phrase "will". The circumstances and actions of the child which can be categorized as endangering the community Assessment of the situation and actions of the child that will endanger this community is very subjective and can lead to multiple interpretations. In this law there is no explicit mention of the criminal offense of a child who can be sentenced to imprisonment is Children aged 14 (fourteen) years or more. Children aged 14 (fourteen) years and committing a criminal offense threatened with a sentence of 7 (seven) years or more have the potential to be sentenced to imprisonment.

This shows that the rules for imprisonment against children (Law Number 11-year 2012 concerning the Child Criminal Justice System) still have weaknesses in the form of conflicts, or vague/ambiguous or legal void that have not materialized justice for Children.

The philosophical basis for the formation of law is that in addition to regulating and disciplining the community, the most important thing is to give a sense of justice to the community. ${ }^{12}$ Budiman Tanuredja illustrates how weak humans must deal with the practice of law enforcement which is chaotic which is merely seeking formal truth, not substantial truth. As a result, people who are legally blind must deal with law enforcers who are very fluent in talking about articles and have the nature to use those who are weak. ${ }^{13}$

In Law Number 11-year 2012 concerning the Child Criminal Justice System several articles restrict the imposition of imprisonment for children, namely:

1. Article 2 letter i, "Deprivation of liberty and punishment as a last resort.

2. Article 3 letter $\mathrm{g}$, which regulates the rights of children in the criminal justice process, Children have the right to "not be arrested, detained, or imprisoned except as a last resort and in the shortest time".

3. Article 81 paragraph (5), "Prison sentences against children are only used as a last resort.

Although Law Number 11-year 2012 concerning the Child Criminal Justice System in some of these articles has limited and strictly regulated the imposition of imprisonment for children, the Judge in prosecuting Child cases tends to impose prison sentences on Children.

The imposition of imprisonment against children is inseparable from several law enforcement factors. Factors that influence law enforcement are among others influenced by several factors, namely, legal regulations (legal Substance), law enforcement factors (legal structure) and legal culture factors (legal culture) that there are still some weaknesses.

\footnotetext{
${ }^{12}$ Umar Sholehudin, 2011, Hukum dan Keadilan Masyarakat,Malang ; Setara Pers, page 64.

${ }^{13}$ Aloysius Soni BI de Rosari, 2010, Elegi Penegakan Hukum, Jakarta : PT. Kompas Media Nusantara, page xi xii. 
Regarding some of the weaknesses in Law No. 11 year 2012 concerning the Child Criminal Justice System, the authors argue that it is necessary to re-arrange (reconstruct) the law. Refusing from the background described above, it is interesting to study it in depth, regarding Implementation Child criminal sanctions in the perspective of Law Number 11 of 2012 concerning the Criminal Justice System of Children in Indonesia, factors that influence unfair criminal sanctions in Children, and Child Criminal Procedure Reconstruction in the perspective of Law Number 11 of 2012 concerning Child Criminal Justice System based on the value of justice.

\section{Research Methods}

This type of research is non-doctrinal or empirical legal research, where the approach is to look at something legal reality in the community and serves as a support for identifying and clarifying findings of non-legal material for legal research needs.

This research is critical/prescriptive analysis, which is criticizing the applicable regulations (positive law) associated with legal theory and its implementation in social life. Critical research, every study must obtain knowledge about das sein (what is) and not das sollen (what should be). In this study the author analyzed and criticized the implementation of Child Criminal sanctions in the perspective of Law Number 11-year 2012 concerning the Child Criminal Justice System why it has not realized justice. It is done by analyzing the provisions regarding child criminal sanctions in the child criminal justice system law in its application by the Judge in the Court.

The sociological juridical approach (socio legal research) was used in this study. This approach was used because the problems are closely related to social reality and real human's behavior, in this case law enforcement actor. Real human behavior must also refer to the social and legal norms in the community concerned.

\section{Research Results and Discussion}

Implementation of Criminal Sanctions Against Children in The Perspective of Law Number 11-Year 2012 Concerning the Child Criminal Justice System in Indonesia

In general, in every criminal case being examined, before deciding on a case, the Judge considers the elements of a criminal act charged by the Public Prosecutor based on the facts at the trial, whether proven or not. If all the elements of a crime in the indictment are proven, then the judge considers whether there is a forgiving reason or even justification in the defendant as a condition of criminal liability, so that the defendant can be convicted or not. The last Judge considered the incriminating things that alleviated the defendant, all of the Judge's considerations were judicial judgments, as a basis for deciding the case.

In the case of a child criminal, there is a difference with a criminal case which is the perpetrator of an adult, in the child case, besides considering juridical factors the Judge must also consider non-juridical (sociological, psychological, criminological) factors. As stipulated in Law Number 11-year 2012 concerning the Child Criminal Justice System. The obligation to consider these non-judicial factors is expressly stated in Article 59 paragraph (3), "Judges must consider social research reports from Community Guidance before imposing case decisions." As a consequence if the judge does not consider sociological factors (Community Research) by the BAPAS (Community Guidance from the Correctional Center) then the decision become null and void, as stipulated in Paragraph (4) "in the event that the social research report as referred to in paragraph (3) is not considered in the judge's decision, the decision is null and 
void." However, in this article there is no Judge's attachment to the results of the Social Research conducted by Community Guidance from the Correctional Center (BAPAS), the judge in deciding on an independent case and may not agree with the advice of BAPAS, the results of the social research are only input that is not binding.

In the reality of the results of the study, at the time of the trial, debates between prosecutors and legal advisers revolved more around the effort to prove criminal acts and very few witnesses stated about the objective conditions (physical, psychological and social conditions) of the Child. In the stage of giving opinions by parents/guardians/foster parents, and Community Counselors, the consideration is more in demand (for example, please make the mildest decision or ask for the fairest decision). It is used as a consideration for the request; because the defendant was young, the defendant had never been convicted, the defendant admitted his actions, the defendant regretted his actions, and these reasons did not provide an explanation of the child's condition so far and the child's future and the risks that might be caused if the decision was handed down. Non-juridical, sociological, criminological and psychological considerations are not considered by those involved in the juvenile justice system. In this study the parties that did not pay attention to the sociological, criminological, and psychological aspects in question were judges, legal counsel, parents / guardians / foster parents of the Children, community officers. The lack of awareness of the parties in paying attention to the non-juridical aspects will have a negative impact on the child, because the criminal sentenced by the court is not necessarily in accordance with the child's situation and a sense of justice in the community. Substantially, there are several Child Judges who still prioritize a juridical approach and pay little attention to non-juridical factors (eg physical, psychological, sociological and criminological side) in order to consider the punishment of children.

Basics of judges' consideration so that they have a tendency to choose to impose criminal sanctions rather than impose actions on children, are juridical considerations and non-juridical considerations. In his consideration, the judge precisely prioritized juridical reasons, namely as the implementation of the provisions of the prevailing laws and regulations, namely because the criminal was allowed to be imposed on the child in accordance with the provisions of Law Number 11 year 2012 concerning the Child Criminal Justice System and The Criminal Code or other provisions of the Criminal Law, that criminal acts are classified in the category of "crime" (as qualified in the Criminal Code I) and disturbing or endangering the public. In nonjuridical considerations, it is more focused as a coaching effort, and because there are doubts about the effectiveness of sanctions in the form of action (maatregel). ${ }^{14}$

The purpose of Law Number 11 year 2012 concerning the Child Criminal Justice System as confirmed in the weighing consideration is "to protect the dignity of the child, which the child is the mandate and gift of the Almighty God who has full human dignity so that the Republic of Indonesia provides protection specifically, especially legal protection in the justice system ".

Judges in making non-juridical (sociological) considerations only express expert thoughts and opinions which are only theoretical. The judge did not consider the psychological factors of the child at all, both from the personal character of the child, the family environment, the educational background of the child, the environment of the child's association, the

\footnotetext{
${ }^{14}$ Sri Sutatiek, 2013, Rekonstruksi Sistem Sanksi Dalam Hukum Pidana di Indonesia Urgensi Penerbitan Panduan Pemidanaan (The Sentencing Guidelines) Untuk Hakim Anak, Yogyakarta, Aswaja Pressindo, page 32. Copyright $\odot$ GLOBAL ACADEMIC EXCELLENCE (M) SDN BHD - All rights reserved
} 
psychological consequences of the child undergoing punishment, and the motive of the child to commit a crime. Then in his consideration the judge stated his reasons as the basis for imprisonment, namely because there was no other alternative and readiness from the Provincial Social Service and the Social Service Office of the Banjarbaru City to accept Children Conflicting with the Law if the child was sentenced in the form of action. On the other hand, in the Criminal Justice System Act the action that can be imposed on Children is not only in the form of care at the LPKS (Child Welfare Organizing Agency) organized by the Social Service Office. However, there are still several alternative types of actions that can be imposed on Children as stipulated in Article 82 paragraph (1), such as being returned to parents, even if the judge imposes a sentence on the child, imprisonment is not the only type of crime that can be imposed on the child as stipulated in Article 71 paragraph (1) and paragraph (2). In Article 73 paragraph (1), it is also regulated regarding the imposition of a conditional sentence, namely, "a criminal under conditions that can be imposed by a judge in terms of imprisonment imposed for a long period of 2 (two) years". In this case the judge imposes a sentence of imprisonment against the Child, ranging from an average of 2 (two) months to 2 (two) years, so that it is possible for the judge to impose a conditional sentence on the child, not necessarily imprisonment.

Judges also always use the provisions of Article 81 paragraph (1) as the basis for imposing imprisonment on children, the article reads, "Children are sentenced to prison in LPKA (Child Correctional Institution) if the circumstances and actions of the child endangers the community". In this case the standard of conditions and actions of the Child will endanger the community is unclear, so that this article can be easily used as a basis for imprisonment against Children. Other considerations in imposing imprisonment on a judge's child always contain the main consideration, "because the child can be accountable for his actions so as to provide" lessons "so that the child becomes deterrent and does not repeat the reproduction in the future". Such considerations as if the purpose of the sentence imposed on the Child is aimed at providing a deterrent effect on the Child, not as an effort to provide guidance to the Child, such considerations clearly contradict Article 2 letter d, the principle of the best interest for the Child, letter g coaching and guidance Child and letter $\mathrm{j}$ avoidance of retaliation.

Criminal Sanctions Against Children in The Perspective of Law Number 11 of 2012 Concerning the Child Criminal Justice System Have Not Yet Realized Justice

Child Criminal Justice aims to provide the best for the child, without sacrificing the interests of the community and upholding the authority of the law. ${ }^{15}$ Children as the younger generation are the successors of the ideals of the nation's struggle and human resources for national development. In order to realize quality human resources in Indonesia and be able to lead and maintain national unity, continuous coaching is needed for survival, growth and physical, mental and social development and protection from all possibilities that will make children happy in the future.

Juvenile justice is held with the aim of re-educating and improving the attitudes and behavior of children so that they can abandon the bad behavior they have been doing so far. ${ }^{16}$ Protection of the interests of the child being cultivated by providing guidance/education in the context of rehabilitation and re-socialization is the basis of juvenile justice. ${ }^{17}$ The restorative justice approach is a mandatory effort, involving the perpetrators, victims, the families of the

\footnotetext{
${ }^{15}$ Maidin Gultom, 2012, Perlindungan Hukum Terhadap Anak dan Perempuan, Bandung Refika Aditama, page 192.

${ }^{16} \mathrm{Ibd}$.

${ }^{17}$ Ibid.

Copyright (C) GLOBAL ACADEMIC EXCELLENCE (M) SDN BHD - All rights reserved
} 
perpetrators/victims, and other parties involved to jointly seek a just solution by emphasizing recovery in its original state, and not in retaliation, and deprivation of independence and punishment as a last resort (ultimum remedium).

To be able to realize child criminal justice that can provide the best protection for the interests of children, it is constrained by several factors. Factors that influence the effectiveness of law are: (a) law factors, (b) law enforcement factors, (c) facilities and infrastructure factors, (d) community factors, (e) cultural factors.

According to Lawrence M. Friedman in Andi Hamzah Law Enforcement in Lightly Patterned Crimes with Restorative Justice, he said that the legal system consists of 3 elements, namely (1) Legal structure, (2) Legal material, and ( 3) Legal culture. ${ }^{18}$ Law enforcement for children who commit criminal acts cannot be separated from the legal system according to Lawrence M. Friedman.

First, the legal structure in the legal system concerns on the Legislative Body (Parliament), the Executive (Government), and the judiciary (judicial power). One of the factors of law enforcement is the law enforcement factor. Judge's professionalism and moral integrity greatly influence the judge's decision. Unprofessional judges tend to make decisions that only prioritize mere formal truths and ignore substantial truths so that their decisions cannot bring about justice.

Second is the legal substance of the legal material itself. It is as a legal method, norms, behavior patterns of society. The legal substance is also court decisions (jurisprudence).

In the law on the juvenile justice system there are a number of articles that can hinder the purpose of juvenile justice. These articles actually become blockages for the realization of justice in realizing the protection of the best interests of children. Obstacles to law enforcement originating from the Act are caused, because:

1. The principles of the entry into force of the Law are not followed.

2. The absence of implementing regulations that are needed to implement the Law,

3. The ambiguity of the meaning of the words in the Law which results in confusion in the interpretation and application.

Several articles on Child criminal sanctions in Law Number 11 year 2012 concerning the Criminal Justice System for Children who have not yet realized justice according to the Author have 4 (four) articles, namely, Article 7 paragraph (2), Article 32 paragraph (2) letter b, Article 71, Article 79 paragraph (1), and Article 81 paragraph (1).

\section{Reconstruction of Criminal Sanctions Against Children in The Perspective of Law Number 11 Year 2012 Concerning the Child Criminal Justice System Based on Justice}

Social justice for all the people of Indonesia is realized through the realization of the principle of justice in every aspect of justice that is law, political economy, social culture and morals are all closely related. Therefore, the values of Pancasila have constitutive functions that determine whether the Indonesian rule of law is the correct legal order, in addition to the regulative function that determines the positive law prevailing in Indonesia is a fair law or not. Thus, the

\footnotetext{
${ }^{18}$ Andi Hamzah, Op.cit., page. 53. 
Fifth Precept of Pancasila, social justice for all Indonesian people, is not implied the formulation of highlighted self-interest, but the interests of the whole Indonesian people. ${ }^{19}$

Based on the values of religious wisdom, especially from the perspective of Islamic law, in the case of any change in legislation in principle, non-retroactive principle is applied, but the principle can be disregarded in accordance with the principle of "dlarar" and "maslahat". This means that in certain cases it can be retroactive as long as the act is very feasible for the security and legal system in society and with retroactive will bring benefit to the perpetrator, victim and society. ${ }^{20}$

Several articles in Law Number 11 year 2012 concerning the Reconstruction of Child Criminal Justice System so that it is expected to realize justice for Children, namely Article 7 paragraph (2), Article 32 paragraph (2) letter b, Article 71, Article 79 paragraph (1), and Article 81 paragraph (1).

\section{Article 7}

(2) Diversion as referred to in paragraph (1) is carried out in the event of a criminal offense committed:

a. threatened with imprisonment under 7 (seven) years; and

b. not a repetition of a crime.

Weakness of Article 7 paragraph (2) letter a can inhibit diversion efforts to achieve restorative justice. By removing restrictions on the types of criminal acts based on the duration of criminal threats which may be attempted to be diversified in paragraph (2) letter a, all child cases are mandatory to be attempted diversion, thus efforts to realize restorative justice can be realized.

The addition of paragraph (3) is an attempt on investigators, public prosecutors and judges to carry out their obligations in doing diversion efforts.

Reconstructed into:

\section{Article 7}

(1) At the level of investigation, prosecution and examination of cases of Children in a district court, diversion must be sought.

(2) Diversion as referred to in paragraph (1) shall be carried out in the event that the crime committed is not a repetition of a criminal act.

(3) Diversion as referred to in paragraph (1) if it is not implemented then the decision is null and void.

\section{Article 32 Paragraph (2)}

Detention of children can only be carried out with the following conditions:

a. Children are 14 (fourteen) years old or more; and

b. Suspected of committing a crime with the threat of imprisonment of 7 (seven) years or more.

\footnotetext{
${ }^{19}$ Anis Mashdurohatun, Hayyan Ul Haq, Sony Zulhuda, Social Function Reconstruction Of Intellectual Property Rights (Ipr) Based On Justice Values, International Journal of Law Reconstruction Volume I, Issue 1, September 2017, page. 148 .

${ }^{20}$ Sri Endah Wahyuningsih and Muchamad Iksan, Reconstruction of the retroactive principle in the Indonesian criminal Law code based on the value of religious wisdom, International Journal of Law Reconstruction Volume I, Issue 1, September 2017, page. 190 
The weakness of Article 32 paragraph (2) stipulates that the conditions for detention in letter $b$ are stated that one of the detention conditions is suspected of committing a criminal offense with a threat of 7 (seven) years or more. Child detention always has implications for imprisonment. To minimize the imposition of imprisonment, the requirement to detain children must be tightened, namely from a criminal offense that is punishable by imprisonment of 7 (seven) years or more is changed into a criminal offense which is subject to a 10 (ten) year prison sentence.

Reconstructed into:

\section{Article 32 Paragraph (2)}

Detention of children can only be carried out with the following conditions:

a. Children are 14 (fourteen) years old or more; and

b. Suspected of committing a criminal offense with the threat of imprisonment of 10 (ten) years or more.

\section{Article 71}

The principal punishment for the Child consists of:

a. criminal warning;

b. criminal terms:

1) coaching outside the institution;

2) community service; or

3) supervision.

c. work training;

d. coaching in institutions; or

e. jail.

Additional crimes consist of:

a. deprivation of profits derived from criminal acts; or

b. fulfillment of customary obligations.

If the material law is threatened with cumulative criminality in the form of imprisonment and fines, criminal penalties are replaced with job training. Crimes imposed on children are prohibited from violating the dignity of the child.

Further provisions regarding the form and procedure for implementing criminal acts as referred to in paragraph (1), paragraph (2), and paragraph (3) shall be regulated by government regulations.

In Article 71 which regulates the types of criminal sanctions against children does not regulate the limits of criminal threats carried out by children who can be imprisoned. In the absence of clear rules on the limits of the length of time the threat of criminal offense committed by the Child allows the Judge to impose all criminal acts committed by the Child sentenced to imprisonment.

Reconstructed, and inserted 1 paragraph into:

\section{Article 71}

The principal punishment for the Child consists of:

a. criminal warning;

b. criminal terms:

1) coaching outside the institution;

2) community service; or 
3) supervision.

c. work training;

d. coaching in institutions; or

e. jail.

Additional crimes consist of:

a. deprivation of profits derived from criminal acts; or

b. fulfillment of customary obligations.

If the material law is threatened with cumulative criminality in the form of imprisonment and fines, criminal penalties are replaced with job training.

Prison criminal as referred to in paragraph (1) letter e can be imposed on the child if the child commits a crime that is threatened with imprisonment of 10 (ten) years or more.

\section{Article 79 Paragraph (1)}

Criminal restrictions on freedom are imposed in the event that a child commits a serious crime, or a criminal act accompanied by violence.

Article 79 regulates the terms and procedures for imposing restrictions on freedom (prison), paragraph (1) there is no certainty regarding the criteria for serious crimes, so that the judge will tend to impose a prison sentence for the child, with his own consideration that the child has committed felony.

Reconstructed into:

\section{Article 79}

Criminal restrictions on freedom are enforced in the event that a child commits a crime that is punishable by imprisonment of 10 (ten) years or more or a criminal act accompanied by violence.

Article 81 Paragraph (1)

Children are sentenced to imprisonment in LPKA (Child Correctional Institution) if the circumstances and actions of the Child will endanger the community.

The provisions of Article 81 paragraph (1) also regulate guidelines for imposing prison sentences on Children. This article provides limits on the actions for imprisonment, namely the circumstances and actions of children that endanger the community, this article also creates uncertainty about what actions or circumstances that are included are harmful to the community. In the formulation of this article, it gives a very broad authority to the judge to assess a situation and actions that endanger the community. The formulation of this article does not provide certainty and will harm the child. Almost all criminal acts can be seen as acts that endanger the community.

Reconstructed into:

\section{Article 81}

Children are sentenced to imprisonment in LPKA (Child Correctional Institution) if the circumstances and actions of the Child will endanger the community, and the criminal offense committed is punishable by imprisonment of 10 (ten) years or more.

More specifically, Law Number 11 of 2012 concerning the Child Criminal Justice System before and after reconstruction can be described and seen clearly in the following table: 


\section{Conclusion}

Implementation of Child Criminal sanctions is in the perspective of Law Number 11-year 2012 concerning the Child Criminal Justice System. Judges in imposing crimes against children tend to apply retributive theories and teleological theories (goals). In the case of a Child, the judge is more likely to decide a sentence of imprisonment against the Child, very few children are subject to action.

Factors that influence the Child Criminal Sanction in Perspective of Law Number 11 year 2012 which are not yet fair, namely: First, the substance of several articles in Law Number 11 year 2012 concerning the Child Criminal Justice System, namely Article 7 paragraph (1) letter a, Article 32 paragraph (2) letter b, Article 71, Article 79 paragraph (1) and Article 81 paragraph (1) there are still weaknesses. Second, law enforcement officials (Judges), in their legal considerations the Judge does not consider the factors that encourage the Child to commit a crime (things outside the law/non-juridical factors), the Judge merely considers juridical facts. The judge in determining the imposition of criminal sanctions also did not consider other alternatives, namely the imposition of actions as stipulated in the Republic of Indonesia Law Number 11-year 2012 concerning the Child Criminal Justice System. Third, the culture of public law, rooted means of society, assumes that every criminal (criminal act) must be sentenced to prison. The community does not understand that if the child commits a crime other than being punished by imprisonment, there are still other alternatives to be subject to action. Several articles in Law Number 11 year 2012 concerning the Reconstruction of Child Criminal Justice System so that it is expected to realize justice for Children, namely Article 7 paragraph (2), Article 32 paragraph (2) letter b, Article 71, Article 79 paragraph (1), and Article 81 paragraph (1).

\section{References}

Abintoro Prakoso, 2012, Pembaruan Sistem Peradilan Pidana Anak, Yogyakarta: Aswaja Pressindo.

Adami Chazawi, 2008, Pelajaran Hukum Pidana Bagian 1, Jakarta: PT RajaGrafindo Persada. Achmad Ali, 2009, Menguak Teori Hukum (Legal Theory) dan Teori Peradilan (Judicial prudence), Kencana Prenada Madia Group, Jakarta.

Aloysius Soni BI de Rosari, 2010, Elegi Penegakan Hukum, Jakarta : PT. Kompas Media Nusantara

Andi Hamzah, 1994, Pelaksanaan Peradilan Pidana Berdasar Teori dan Praktek, Jakarta: PT Rineka Cipta.

Anis Mashdurohatun, Hayyan Ul Haq, Sony Zulhuda, Social Function Reconstruction of Intellectual Property Rights (Ipr) Based On Justice Values, International Journal of Law Reconstruction Volume I, Issue 1, September 2017.

Anis Mashdurohatun,2017, Wa Ode Khatija Rasia, Legal Protection On Children As Victims Of Human Trafficking Based On Justice Values, Jurnal Pembaharuan Hukum, Volume.4, Issue, 2, 2017.

Anis Mashdurohatun and M. Ali Mansyur Identifikasi Fair Use/Fair Dealing Hak Cipta Atas Buku Dalam Pengembangan Iptek Pada Pendidikan Tinggi Di Jawa Tengah, Yustisia. Vol. 4 No. 3 September - Desember 2015.

Barda Nawawi Arief, 2008, Bunga Rampai Kebijakan Hukum Pidana (Perkembangan Penyusunan Konsep KUHP Baru) Edisi kedua, Jakarta: Kencana.Prenamedia Group

Niniek Suparni, 1996, Eksistensi Pidana Denda Dalam Sistem Pidana dan Pemidanaan, Jakarta: Sinar Grafika.

Maidin Gultom, 2012, Perlindungan Hukum terhadap Anak dan Perempuan, Bandung: PT Refika Aditama. 
Meta Suryani and Anis Mashdurohatun,Penegakan Hukum Terhadap Eksistensi Becak Bermotor Umum (Bentor) Berdasarkan Undang-Undang Nomor 22 Tahun 2009 Tentang Lalu Lintas Dan Angkutan Jalan, Jurnal Pembaharuan Hukum, Volume III No.

1 Januari - April 2016

Sudarto, 1981, Hukum dan Hukum Pidana, Bandung, Penerbit Alumni.

Sri Endah Wahyuningsih, Perlindungan Hukum Terhadap Anak Sebagai Korban Tindak Pidana Kesusilaan Dalam Hukum Pidana Positif Saat Ini, Jurnal Pembaharuan Hukum Volume III No. 2 Mei - Agustus 2016.

Sri Endah Wahyuningsih and Muchamad Iksan, Reconstruction of the retroactive principle in the Indonesian criminal Law code based on the value of religious wisdom, International Journal of Law Reconstruction Volume I, Issue 1, September 2017

Sri Sutatiek, 2013, Rekonstruksi Sistem Sanksi Dalam Hukum Pidana Anak di Indonesia, Urgensi Penerbitan Panduan Pemidanaan, Yogyakarta, Aswaja Pressindo.

Umar Sholehudin, 2011, Hukum dan Keadilan Masyarakat,Malang ; Setara Pers.

Undang-Undang Dasar Negara Republik Indonesia Tahun 1945.

Undang-Undang Nomor 11 Tahun 2012 tentang Sistem Peradilan Pidana Anak. 